\title{
IQTISHODUNA
}

Vol. 16 (1), 2020

P-ISSN: 1829-524X, E-ISSN: 2614-3437

\section{Analysis of Strategic Study of Women's Economic Empowerment Program}

\author{
Indah Yuliana \\ Faculty of Economics UIN Maulana Malik Ibrahim Malang, Indonesia \\ E-mail: indahoty@manajemen.uin-malang.ac.id
}

\begin{abstract}
Research objectives; (a) Identify the context of program empowerment undertaken, (b) Conduct an analysis of program approaches and interventions, and (c) Conduct an achievement analysis. In this study, the approach used is a case study approach as part of qualitative research. This research took place in several villages in Blitar that received the Poverty Feminization program. Sampling in this study using the snowball sampling method. Data collection techniques used in this study were interviews and observation. Data analysis is done by organizing the data, breaking it down into units, synthesizing it, arranging it into patterns, choosing what is essential and which is not essential and what will be learned, and making conclusions. The results showed (1) The context of the empowerment of this program was the head of the women's household, (2) The stages in the implementation of women's economic empowerment were carried out from the upstream to downstream sectors including the preparation phase, the assessment stage, the realization of aid, the implementation of monitoring, and the intervention of the Jalin Matra program implementation. (3) Achievement, economic empowerment carried out through poverty feminization prevention programs in general, provide positive values for the lives of the target KRTP.
\end{abstract}

Keywords: Women's economic empowerment.

Abstrak: Tujuan penelitian (a) Mengidentifikasi konteks pemberdayaan program yang dilakukan, (b) Melakukan analisis pendekatan dan intervensi program, dan (c) Melakukan analisis ketercapaian. Dalam penelitian ini pendekatan yang digunakan adalah pendekatan studi kasus sebagai bagian dari penelitian kualitatif. Penelitian ini mengambil lokasi di beberapa desa di Blitar yang menerima program Feminisasi Kemiskinan. Pengambilan sampel dalam penelitian ini menggunakan metode snowball sampling. Teknik pengumpulan data yang digunakan dalam penelitian ini adalah wawancara dan observasi. Analisa data dilakukan dengan mengorganisasikan data, menjabarkannya kedalam unit-unit, melakukan sintesa, menyususn kedalam pola, memilih mana yang penting dan yang tidak penting dan yang akan dipelajari, dan membuat kesimpulan. Hasil penelitian menunjukkan (1) Konteks pemberdayaan program ini adalah kepala rumah tangga perempuan, (2) Tahapan dalam pelaksanaan pemberdayaan ekonomi perempuan dilakukan dari sektor hulu hingga hilir meliputi tahap persiapan, tahap assessment, realisasi bantuan, pelaksanaan monitoring, dan intervensi pelaksanaan program Jalin Matra (3) Ketercapaian, pemberdayaan ekonomi yang dilaksanakan melalui program penanggulangan feminisasi kemiskinan secara umum memberikan nilai yang positif bagi keseluruan kehidupan KRTP sasaran.

Kata kunci: Pemberdayaan ekonomi perempuan. 
| Received February 2019 |Accepted March 2020 | Available online April 2020 |

| DOI: http: //dx.doi.org/10.18860/iq.v16i1.6354

\section{How to Cite:}

Yuliana, I. (2020). Analysis of Strategic Study of Women's Economic Empowerment Program. Iqtishoduna. Vol. 16 (1): pp 1-16.

\section{Introduction}

Poverty alleviation by the central and regional governments does not run smoothly. Some research results indicate the factors that cause the failure of poverty alleviation programs in Asian and African countries, by: (1) Because of the 'target' and 'top-down' approach; (2) Ignoring local values and 'outsiders' bias; (3) Lack of participation; (4) approach that is not holistic; and (5) Illusion of investment (Muktasam, 2001). In terms of 'target' and 'topdown' approaches, poverty alleviation programs often specify goals without involving the poor themselves. Chambers (1983) persuasively explains the neglect of local values; the non-participatory empowerment program is the chain of failure of the empowerment program. The results of Dharmantaka's research (2015) showed that the target community that should have been independent turned out to be spoiled (wanted to be served) and dependent on the assistance provided. Business credit assistance provided under the "Revolving Loan" concept is considered to be granted that are not required to be returned, resulting in bad credit and no settlement.

Tragically, they see it as ordinary and mediocre. The same thing happened in Siak Hulu Subdistrict, Kampar Regency, as stated in the results of Fitriani and Rusli's research (2014). Even worse, there are corrupt mental managers. The manager misused the refunded funds. On the other hand, financial assistance is not able to grow the social capital of the target community. Instead, it eliminates mutual-cooperation and self-help culture in developing their territory (Sumelung, 2016). This is evident in infrastructure development activities. The culture of cooperation and community self-help gradually began to disappear (Hadi et al., 2013; Nurkatamso and Listyaningsih, 2013). Workers in infrastructure development are not voluntary workers anymore, but workers who are given a salary, even though they work in their area or property. Therefore, the success of infrastructure development is not caused by the amount of social capital of the community but rather is caused by the number of budget funds spent.

Proper empowerment must be able to create a climate that can develop the potential of the community, strengthen the potential of the community, 
and protect or protect the weak so that people are not exploited by influential people (Mardikanto, 2010). Therefore, community empowerment aims to make the community independent and able to overcome its problems, not make the community dependent on outsiders. There are still many empowerment programs that make people dependent and not independent (Fitriani and Rusli, 2014; Dharmantaka, 2015).

The Provincial Government of East Java has a unique economic empowerment program for women, especially households that our Head of Women's Households (KRTP). Blitar Regency is one of the regions in East Java channelling Rp. $1,901,623,000$ to the poor and poor widows in Blitar, especially for female household heads, such as widows and homemakers who have been left by their husbands for years, without news and still productive. This researcher wants to comprehensively assess and analyze the design of women's empowerment programs/interventions to see their relevance to improving the conditions of women with specific poverty characteristics, regarding the context of empowerment, the scope and size of success and to map existing policies. Research objectives (a) Identifying the empowerment context of the programs undertaken, (b) Analyzing approaches and interventions carried out in women's economic empowerment programs, (c) Conducting analyzes of achievements in women's economic empowerment programs.

\section{Literature Review \\ Poverty}

The problem of community poverty in these countries is not just a form of income inability but has expanded to form socially and politically powerless (Suryawati, 2004). Poverty is also considered as a form of development problems caused by the negative impact of unbalanced economic growth thereby widening the income gap between communities and the income gap between regions (inter-region income gap)(Harahap, 2006). In general, poverty is defined as a condition of income inability to meet basic needs so that it is less able to guarantee survival (Suryawati, 2004).

The ability of income to meet basic needs based on specific price standards is low, so it does not guarantee the fulfilment of quality of life standards in general. Based on Law No. 24 of 2004, poverty is a socioeconomic condition of a person or group of people whose fundamental rights are not fulfilled to maintain and develop a dignified life. Basic needs that are the right of a person or group of people include the needs of food, health, education, employment, housing, clean water, land, natural resources, the environment, a sense of security from the treatment or threat of acts of violence, and the right to participate in organizing social life and politics. The People's Welfare Sector 
report issued by the Ministry of Welfare (Welfare) in 2004 also explained that the condition called weak also applies to those who work, but their incomes are insufficient to meet basic/basic needs.

The poverty trap stated by Chambers explains how the so-called poor conditions in most developing countries and the third world are conditions called impoverishing. Conditions that are mostly found that poverty is always measured/known based on the low ability of income to meet basic needs in the form of food, health, housing or settlement, and education. The low ability of income is also interpreted as low purchasing power or ability to consume. The ability of income that is relatively limited or low causes the purchasing power of a person or group of people, especially to meet basic needs to be low (Nugroho, 1995).

The conditions due to limited or low income above cause the formation of public health status, which is said to be low (morbidity) or is in a low nutritional condition. This condition is very vulnerable to disease and malnutrition, which is accompanied by high mortality. A high mortality rate and a low state of public health will have an impact on low social participation, higher absenteeism, low intelligence, and relatively low skills.

The four forms of poverty are (Suryawati, 2004): (a) Absolute Poverty, Absolute Poverty is a condition where the income of a person or group of people is below the poverty line. Hence, it is insufficient to meet the standard requirements for food, clothing, health, housing and education needed to improve the quality of life. The poverty line is defined as an average expenditure or average consumption for basic needs related to the fulfilment of welfare standards. This form of absolute poverty is most often used as a concept to determine or define the criteria of a person or group of people called weak. (b) Relative Poverty, relative poverty is defined as a form of poverty that occurs due to the influence of development policies that have not yet reached all levels of society, causing income inequality or inequality in welfare standards. Areas that have not been reached by development programs like this are commonly known as disadvantaged areas. (c) Cultural Poverty, Cultural Poverty is a form of poverty that occurs as a result of the attitudes and habits of a person or society that generally comes from culture or customs that are relatively unwilling to improve living standards with modern procedures. Habits like this can be lazy, wasteful or never economical, less creative, and also relatively dependent on other parties. (d) Structural Poverty, Structural Poverty is a form of poverty caused by low access to resources which generally occurs in a socio-cultural or socio-political order that is less supportive of poverty relief. This form of poverty also sometimes has a discriminatory element. Form of structural poverty is a form of poverty that receives the most attention in the social sciences, especially among 
aid/loan countries such as the World Bank, IMF and Asian Development Bank. Forms of structural poverty are also considered to most cause the existence of the three forms of poverty mentioned earlier.

\section{Empowerment}

Prijono and Pranarka (1996) explained that empowerment is a process for the community to become empowered, encourage or motivate individuals to have the ability or empowerment to determine their life choices and empowerment must be aimed at the groups or layers of society that are left behind. According to Mubyarto (1997), empowerment is an effort to increase the ability of the community by developing and dynamizing its potential. Starting from that is not only the economy improving but also dignity, dignity, self-confidence and self-esteem.

The process of empowering the poor according to Prijono and Pranarka (1996), can be carried out in stages in three phases, namely: first, the financial phase. All empowerment processes come from the government by the government and are intended for the people. Second, the participatory phase is the process of empowering the government together with the community that has been actively involved in moving towards independence. Third, the emancipatory phase is process empowerment of the people and for the people and supported by the government together with the people.

\section{Women Empowerment}

Women's empowerment is a new paradigm of development that emphasizes the characteristics of "people-centred, participatory improving and sustainable" (centred, active participation). This concept was developed by many experts and practitioners to look for an effort called "alternative development" which calls for "inclusive democracy", inclusive economic growth, gender equality and intergenerational equality "(proper economic growth, gender equality and intergenerational equality) (Kartasasmita, 1996). When compared with men, women are more exposed to networks of power that trap them in a standard image that worries them (Dzuhayatin, 1996).

The concept of empowerment as a paradigm has also been reviewed by Moser (1993). Empowerment strategies are not intended to create women who are superior to men. Although this empowerment approach realizes the importance of increasing women's power, this approach seeks to identify power not only in terms of one's domination of the other but rather within the framework of women's capacity to increase independence and internal strength.

\section{Research Method}

This type of research in this study is qualitative research. In this study, the approach used is a case study approach as part of qualitative research. The 
villages selected in this study were villages that received the poverty feminization program (PFK) in Blitar. The selection of Blitar as the object of research is based on the proximity of the object to the residence of the researcher. The villages are (1) Slorok and Sidodadi Villages, these two villages have quite strategic market potential compared to other villages that receive PFK programs in Garum Subdistrict, in addition to the businesses run by KRTP program recipients also vary, (2) Sumberagung Village and Sukosewu, these two villages are included in the rural suburbs in Blitar District, the businesses run are not so diverse, the livestock business is run much more than the trading business, (3) Karangsono Village where this village is a village whose commodity is agro-tourism, (4) Selopuro Village where Selopuro village is the village with the second-highest number of PFK recipients in Blitar District in the 2016 fiscal year. Sources of data in this study include primary data (human) and secondary data (non-human).

Primary data sources in this study are (1) Kadin PMD (Head of Community and Village Empowerment Service) of Blitar Regency, (2) Kasi PMD (Head of Community Empowerment Section) District, (3) Program facilitators at the district / sub-district / village level, (4) The Head of the Women's Household who is the target of the feminization of poverty program. The four informants in the study were based on the knowledge and information held by the informants related to PFK. Secondary data sources in the form of supporting documents such as Regency / sub-district / village DPMD administration. The selection of informants using the snowball sampling method is to identify, select and take samples in the network or chain of relationships that are associated with PFK.

Researchers present a network through socio gram images in the form of circles that are linked or connected by lines. Each circle represents one respondent or case, and the lines show the relationship between respondents or between cases. The sample is obtained through a process of scrolling from one respondent to another; usually, this method is used to explain the social or communication (sociometric) patterns of a particular community. In snowball sampling, initial identification starts with a person or case that falls within the research criteria. Then based on the relationship of direct or indirect linkages in a network, the next plan or next sample unit can be found. Thus, this sampling process runs until enough information is obtained, and the number of samples sufficient and accurate to be analyzed in order to draw research conclusions. The data in this study are secondary data and primary data. Researchers used to interview and in-depth observation techniques to obtain research data. Interviews were conducted with selected informants under informants' understanding of PFK. Data triangulation or the process of confirming the reliability of the interview results is done by observation. The 
observations made in the study were to look directly at the PFK planning, implementation and evaluation process. Data analysis is done by organizing the data, breaking it down into units, synthesizing, sorting into patterns, choosing what is relevant and not essential and what is learned, and making conclusions.

\section{Results}

\section{Empowerment Identification}

Economically, women have low access to economic resources and have little control over their assets. As is usually the case in rural areas, most women work in agriculture-based sectors. However, women do not have control over land as the primary source of this sector. In rural areas, women mostly work in agriculture-based sectors. However, women do not have control over land as the primary source of this sector. Problems and poverty conditions faced by households by female household heads (KRTP) are generally more chronic when compared to male household heads. KRTP experiences not only problems in the economic sector but also psychological, social and cultural problems. Women allocate a large portion of their income to meet the nutritional needs of their families and are more concerned with the basic needs of their families when compared to men. The higher the income of women, the less likely family members or children suffer from malnutrition. In other words, if it succeeds in overcoming poverty which is increasingly faced by women, the impact or benefits obtained will multiply (multiplier effect). When compared with men, women are more exposed to networks of power that trap them in a standard image that upsets them.

Politically, women in this research area are under-organized. They are not part of a community group or forum where they can share their aspirations. They have very low self-confidence, self-esteem and leadership. They do not make much effort to expand their business, because they understand themselves as earning only the side for their family. Because no head of the family, they do not participate in public spaces. This causes them to lack information, knowledge and skills due to limited access to training and capacity building events, which in turn brings them back to poverty. On the other hand, their contribution to family income and local economic development is less recognized.

\section{Phase and Intervention}

The stages in the implementation of women's economic empowerment are carried out from the upstream to downstream sectors. The preparation phase is the preparation of officers and field preparation. The preparation of the officers is to equalize the perceptions among the facilitator team members regarding the approach to be chosen, while the preparation of the field is 
intended to make the feasibility of the area to be targeted for empowerment. In the process of fulfilling the successful implementation of the PFK program, the same perception is carried out from the provincial socialization to the socialization of the village, which is accommodated in the community consultation meeting. Provincial and district socialization is carried out and facilitated directly by the provincial DPMD as the leading sector in this program, the agenda of activities carried out in this process is an explanation of PFK, synchronization and integration of programs or activities to support PFK and discuss follow-up plans for implementation.

Whereas Subdistrict and village socialization is carried out by district facilitators facilitated by district DPMD which is carried out through preconsultation and community consultation meetings, a pre-residents meeting is a special meeting held before the community consultation which aims to prepare for the implementation of community consultation with the agenda of establishing and establishing village secretariat and selection of potential village facilitators. This activity is carried out by the village government and facilitated by the district facilitator and the sub-district facilitation team. Whereas the residents' meeting was an activity organized by the village secretariat where the activity was facilitated by the District facilitation team and Regency facilitators, this activity aimed to explain to stakeholders about the PFK, to socialize the village secretariat and the village assistant where the activity was attended by all members of the village secretariat, BPD, Kasun RTS location, KRTP representatives, community leaders and village assistants.

However, in the implementation of the communication that was built in the socialization activities, this did not always run smoothly, the lack of proactivity of the communication carried out by the district and sub-district facilitators triggered information imbalance on one side, this also triggered the estrangement of relations between the two. However, as far as the implementation of these program activities in the field, everything went according to the applicable SOP. This pre-consultation and community consultation meeting was also used as a media approach between the companion and target KRTP. Whereas the target area of this program has been determined by the East Java provincial government every year, the regions or villages that receive this program assistance rotate from one region to another so that program equity can occur.

The Assessment Phase is the stage of identifying problems felt by the targets of the empowerment program as well as identifying what resources the targets have. This process is through the fermentation of beneficiaries, wherein the activity of beneficiary verification; there are criteria for beneficiary eligibility. If after verification, it turns out that the target KRTP is not under these criteria, the target KRTP can be replaced through citizen 
consultation with direct assistance by district facilitators. In the implementation of this fermentation, it is essential to have a role between the Village Head and his apparatus so that in the process of the verification and replacement of KRTP that is not following the program criteria can run smoothly, safely and transparently. However, in its implementation in the field, the data dropped by the Provincial Government did not experience many shifts. After identifying the problem the next stage of empowerment is an alternative planning program wherein at this stage the district facilitator or village facilitator participates in trying to engage the community to think about the problems they face and their solutions.

This activity is focused on points six and seven, namely the formation of community groups and the deepening of the needs of KRTP program targets. The formation of pokmas is based on the similarity of types of businesses or the closeness of houses, in the community groups, the group leaders and treasurers have formed as well as the group's follow-up plans. The Pokmas formed by the KRTP in its structure must have a chairman and treasurer, determining who becomes the chairman and treasurer is discussed together with members of the pokmas accompanied by village assistants. However, in the village implementation, the facilitators find it challenging to find the chair and treasurer of the pokmas because of the educational background of the target KRTP still low. The activity of deepening needs is adjusted to the expertise, needs and desires of the target RTP concerned, but if the target KRTP does not have any expertise in the business world and the KRTP wants skills training to support the business to be carried out, in this case, Blitar Regency DPMD provides training facilitation for that matter.

Nevertheless, so far there are no targeted KRTPs that are interested in carrying out these skills training to support the business activities that will be carried out, these target KRTPs prefer to run livestock businesses rather than productive economic or trade ventures where livestock business is not very desirable by program people because one of the objectives of East Java Provincial Government to disburse this assistance is to foster the creative economy of the community, especially KRTP through the business world. Welfare is said to be one of the essential elements in efforts to increase women's empowerment. It cannot be denied that in access to welfare, women occupy an unfavourable position.

After the alternative planning stage, an action formulation is carried out on what the KRTP failed at the previous stage in the form of writing or submitting a proposal following point eight, namely the submission of the disbursement of funds. Submission of this fund disbursement is made through the pokmas where KRTP must write their ideas in the form of proposals, and this activity is fully facilitated by village facilitators because it is not possible if 
carried out by the target KRTP where the majority of the target KRTP education is still relatively low. The process of fulfilling the successful implementation of program points nine through twelve enters into the implementation phase of empowerment where at this stage funds are disbursed from the provincial government to the target KRTP through the villages and community groups that have been formed.

The funds from the provincial government have been designated for whatever purpose when the funds are received by the target KRTP, of which at least $70 \%$ of the funds received are allocated for business capital, a maximum of $30 \%$ is allocated to supporting businesses or charity (sustainable food houses). If the target KRTP requires some of these funds are for meeting basic needs, then the funds can be used a maximum of $10 \%$. This allows them to get capital in the context of developing their (family) business.

Provision of disbursement of funds from the village to the KRTP program target should be implemented in two terms. However, in its implementation not all village governments realize the assistance to the target KRTP in the two terms and following the allocation allocations determined by the provincial government due to differences in the needs of the majority of KRTP villages one is different with the needs of the majority of other villages KRTPs, one that affects this is differences in natural conditions, economic conditions and the characteristics of one village community and the other is indeed different.

The next stage is the realization of aid, the realization of this assistance is carried out by KRTP through the guidance and monitoring of the head of the pokmas, the village assistant and the village secretariat. In the realization of business investment in the form of business infrastructure needed by KRTP in order to develop or open a new business, all activities undertaken by KRTP in realizing the assistance are accompanied directly by the village assistant. Managing funds for businesses is claimed to be an entry point for women for economic empowerment. It educates women to manage money by having small but routine savings, open access to secure cash for daily needs and or starting a business or to expand an existing business.

After the assistance is realized and carried out, then the business carried out by KRTP is evaluated to the extent to which the success of the management of the assistance which will then be accounted for by the government. In the evaluation process the government carries out monitoring activities on the development of the business carried out by the target KRTP, monitoring is carried out in the second or third month after the realization of the program. The monitoring is deemed ineffective if the monitoring carried out by the government aims to see the development of the business carried out by KRTP because if the monitoring distance is very close to the time of program realization, the assistance received to KRTP is undoubtedly still in a 
conducive running condition, different if the monitoring is carried out one or two years after the program is realized.

Contribute to women earning income by starting a small business or increasing an existing business that is managed by themselves or a family. Savings are significant for safe household investment and livelihoods, especially for women. Poor women and families usually do not have enough savings because most of the income goes to basic needs. This, in turn, falls into poverty into the trap of poverty (Mahmudi, 2007). This is even worse for women in whom they have to take responsibility for 'providing' the basic needs of the family. It is essential to note the achievement of NGO efforts to pursue poor women to have better capacity in financial management and to have financial savings as part of poverty alleviation activities.

In terms of saving the micro and loan schemes, other cages or groups can trap poor women into worse poverty situations. In low-income families, where their income meets basic needs, they tend to borrow money from moneylenders. Care must be taken for the pen or group in this situation to avoid that its role is only to replace loan sharks or even to be one source of easy cash loans. As members of the stable, they access loans with more accessible schemes. This also has the potential to open up more financial burdens for women, as happened in Rokan Hilir District. Due to losses (nonperforming loans), cooperative managers carried out several times on the confiscation of goods such as refrigerators, beds, satellite dishes and even land to members because of the inability to repay loans.

The last stage of empowerment activities according to Isbandi Rukminto is the termination or formal termination with the target community, namely KRTP, this stage should be done when the RTS can be independent and not because the funders have stopped their assistance. Formally in the PFK Jalin Matra program, the termination or termination is done when the funder stops his assistance, but informally the termination is not carried out by the implementers at the lowest level, namely the village. Although formally the PFK activities have been completed, the village facilitators continue to monitor the development of the business carried out by the KRTP program targets through existing community and daily activities.

The process of fulfilling the success of the program at the termination stage is the continuity of the program, even though the program has been formally terminated, in this case, the provincial government through the district facilitator facilitates and monitors the target KRTP through the lurik web network (the retail network of young sedulur business groups) or mother care Jaim provided. Through this website, the district facilitators promote the businesses carried out by the target KRTP, the businesses that are promoted by the district facilitators are businesses that fall into the running or 
developing category. Besides being used to promote the business carried out by the target KRTP, this website also functions to link the target KRTP program with various social institutions, so in addition to the sustainability factor, this web program has social value.

Intervention for the implementation of the Poverty Reduction Feminization Matra Control program involves (1) the Provincial management organization, the provincial management organization headed directly by the governor of East Java where one of his tasks and responsibilities is to provide direction to the East Java Provincial East Kalimantan Interlocking Matrix program secretary and the SKPD of the technical advisor in implementing the program. At the provincial level, a Poverty Reduction Coordinating Team (TKPK) was formed which functions as a forum for sectoral and cross-sectoral coordination of poverty alleviation stakeholders at the provincial level. One of the tasks and responsibilities of the Provincial TKPK, namely supervising and controlling the implementation of program activities, coordinating and monitoring programs, synergizing through synchronization, harmonization and integration of programs all of which have accountable results to the governor. The last stakeholders at the provincial level are the provincial facilitator. The provincial facilitator is the supporting staff and the provincial secretariat partner in managing PFK activities from the Higher Education, the tasks and responsibilities of the provincial assistant include: assisting the provincial secretariat in managing the program, together with the provincial secretariat recruiting the personnel assistance, facilitating post-program assistance by the village government. The university which is the provincial government partner in implementing this program is Brawijaya University Malang, which in its implementation is carried out by the Community Service and Research Institute (LPPM) Universitas Brawijaya Malang.

(2) Regency management organization, at the district level the direct management organization by the Regent in which one of the tasks and responsibilities is to establish and determine the District Interlocking Secretariat, determine the allocation of funds to support activities, provide guidance and direction to the district Interlocking. Interlocking Program secretariat in its implementation where the secretariat.

The district is headed by the head of the District Community Empowerment office with members of the relevant SKPD staff whose tasks and functions include: compiling local policies that support the implementation of the Jalin Matra program while still referring to the General Guidelines and PTO, carrying out the document verification of the disbursement of financial assistance specifically the Jalin Matra program and submit to the provincial secretariat. The district facilitators themselves are assistants assigned by the tertiary institutions to facilitate the implementation 
of the PFK Matra Interlace at the district level where one of the tasks and responsibilities is: assisting the district secretariat in facilitating the implementation of PFK Matra Intermediaries in the district, facilitating the village secretariat in implementing the program. (3) Subdistrict management organizations, Subdistrict management organizations consisting of subdistrict facilitation teams consisting of sub-district heads, community empowerment section assisting the district secretariat in guiding, monitoring, evaluating, and reporting on Jalin Matra activities. However, in its implementation, the tasks of the sub-district facilitation team are mostly carried out by the community empowerment section.

(4) Village Government, the organizations involved in the village government, namely the village secretariat and the village assistant. The village secretariat is the person in charge at the village level whose members consist of the Village Head as the person in charge, the Chair of the BPD as the Supervisor, the LPMD Chair as the Chair, the village secretary as the secretary and the village treasurer as the treasurer. One of the tasks and responsibilities of the village secretariat is carrying out RTS verification, facilitating the implementation of socialization through community consultation meetings, monitoring and coaching the realization and marking of aid in KRTP. Village facilitators are assistants assigned by the village government to facilitate the implementation of PFK in the village, which accompanies the pokmas and KRTP in the implementation of PFK Intertwining, the task and obligation of village escorts is to facilitate all activities of the KRTP in the implementation of the PFK Intertwining program by the General Guidelines and Applicable PTO.

(5) Community Groups (pokmas), Community groups are a group of KRTP who voluntarily agree to join in the framework of business development and strengthen social capital whose members consist of a maximum of 20 KRTP and or pay attention to the closeness of the residence, the composition of the pokmas management consists of the chairman and treasurer originating from the target KRTP. This Pokmas functions as a liaison institution in order to streamline aid disbursement, KRTP business realization and business guidance and network development. One of the tasks and responsibilities of the pokmas management is opening an account in the name of the KRTP group, distributing the disbursement of aid funds to members of the pokmas in stages, coordinating and monitoring the progress of the realization of member assistance, coordinating the realization of group joint business activities and conducting group meeting activities regularly.

\section{Achievement}

In implementing the Poverty Feminization Prevention program, there are three success criteria for the management of assistance provided to the target KRTP; these criteria are running or developing, stagnating and failing. 
Running or developing is the condition of the program can be implemented and provide benefits to program recipients. Stagnant is the condition that there is no difference in program recipients before and after program implementation. Failure is the condition of the program; giving makes the recipient of the program depend on the program. These three criteria describe how much impact the PFK program has had on the economy of the target KRTP.

The criteria for running or developing are felt by most of the recipients of the program as seen from the efforts made from the results of the KRTP, able to support their daily needs, and can even set aside some of the income for savings and future planning. A small proportion of program recipients experiences stagnant criteria. This can be seen from the KRTP program implementation, but the results are not able to cover the daily needs of program recipients. Meeting daily needs still relies on other efforts made by program recipients. However, both for developing criteria and stagnant program recipients get new ownership of assets or capital. Besides, there are no criteria for failure in implementing PFK for program recipients.

\section{Conclusion}

The context of the empowerment of this program is the female household heads, such as widows and homemakers who have been left by their husbands for years without news and are still productive. The stages in the implementation of women's economic empowerment are carried out from the upstream to downstream sectors. The Assessment Phase is the stage of identifying the problems felt by the targets of the empowerment program while identifying the resources owned by the targets. Realization of assistance, the realization of this assistance is carried out by KRTP through the guidance and monitoring of the head of the pokmas, the village assistant and the village secretariat. Monitoring implementation. PFK Intertwine program implementation interventions involve (a) Provincial management organizations, (b) District management organizations, (c) District management organizations, (d) Village Government, and (e) Community Groups (pokmas). Achievement, economic empowerment carried out through poverty feminization prevention programs, in general, gives a positive value for the overall life of the target KRTP.

Suggestions in this study are; a) for the community or in particular, KRTP must utilize and optimize the PFK program aimed at improving the household economy and also the surrounding community. It is expected that after the program is completed, with the capital that has been received KRTP can run, manage and develop its business independently, b,) for the government must deepen the needs, abilities and willingness of the target 
KRTP in carrying out the business to be run so that when the program is finished assistance received to KRTP will not be lost or sold. Besides, when monitoring is carried out by the government it is felt that the distance is very close if it is carried out two or three months after the realization of the program, the monitoring should be carried out by the government at least one year after the realization of the program, so that the sense of responsibility of the KRTP to continue managing the businesses it runs is still well nurtured.

\section{References}

Chambers, R. (1983). Rural Development: Putting the Last First. UK: Longman, Harlow.

Dharmantaka R. (2015). Evaluasi Pelaksanaan Pinjaman Bergulir Program Nasional Pemberdayaan Masyarakat (PNPM) Mandiri di Kota Batu. Jurnal Ilmiah Mahasiswa FEB. Vol. 3 (1). Pp: 3-13.

Dzuhayatin. (1996). Agama dan Budaya Perempuan: Mempertanyakan Posisi Perempuan Dalam Islam, Dalam Buku Sangkar Peran Gender, Irwan Abdullah. Yogyakarta: PPK-UGM.

Fitriani., Rusli, Z. (2014). Evaluasi Pelaksanaan Program Nasional Pemberdayaan Masyarakat (PNPM) Mandiri di Kecamatan Siak Hulu Kabupaten Kampar. Jurnal Online Mahasiswa Bidang Ilmu Sosial dan Politik. Vol. 1 (1). Pp: 1-15.

Kartasasmita, G. (1996). Pembangunan untuk Rakyat: Memadukan Pertumbuhan dan Pemerataan. Jakarta: PT. Pustaka Cidesindo.

Hadi AR, Effendi I, Hasanuddin T. (2013). PerananKader Pemberdayaan Masyarakat Desa (KPMD) dan Partisipasi Masyarakat pada Program Nasional Pemberdayaan Masyarakat Mandiri Pedesaan (PNPM-MP) di Kecamatan Wonosobo Kabupaten Tanggamus. Jurnal Ilmu-Ilmu Agribisnis. Vol. 1 (1). Pp: 66-72.

Mahmudi. (2007). Manajemen Kinerja Sektor Publik. Yogyakarta: UPP STIM YKPN

Mardikanto T. (2010). Konsep-Konsep Pemberdayaan Masyarakat: Acuan bagi Aparat Birokrasi, Akademisi, Praktisi dan Peminat/Pemerhati Pemberdayaan Masyarakat. Surakarta (ID): Fakultas Pertanian Universitas Sebelas Maret.

Moser, C.O.N. (1993). Gender Planning and Development: Theory, Practice, and Training. London: Routledge.

Mubyarto. (1997). Ekonomi Rakyat Program IDT dan Demokrasi Ekonomi Indonesia. Yogyakarta : Aditya Media.

Muktasam, A. (2001). Why rural credit programs fail: lessons learned from Indonesian rural development programs. Paper presented at microfinance for agricultural producers in NTB, Indonesia workshop. 
November 15 th, 2001.

Nugroho, H. (1995). Kemiskinan, Ketimpangan dan Kesenjangan. Yogyakarta: Aditya Media

Nurkatamso A, Listyaningsih U. (2013). Tingkat Partisipasi Masyarakat dalam Program Fisik Program Nasional Pemberdayaan Masyarakat Mandiri Pedesaan di Kecamatan Nanggulan Kabupaten Kulon Progo, Yogyakarta(ID): Jurnal Bumi Indonesia. Vol. 2 (2). Pp: 63-67

Prijono, O.S., dan Pranarka, A.M.W. (1996). Pemberdayaan: Konsep, Kebijakan dan Implementasi. CSIS. Jakarta.

Sumelung R.M. (2016). Evaluasi Program Nasional Pemberdayaan Masyarakat Mandiri Pedesaan dalam Meningkatkan Kesejahteraan Masyarakat. Jurnal Eksekutif. Vol. 1 (7). Pp: 1-7.

Suryawati. (2004). Teori Ekonomi Mikro. Yogyakarta: UPP. AMP YKPN. 